\title{
THE PARODY DEFENSE AGAINST TRADEMARK BULLIES: ANALYSIS OF THE LOUIS VUITTON VS. MOB CASE
}

\author{
DANIELA MOLANO LOZANO* \\ (RESEARCH ASSISTANT ON INTELLECTUAL PROPERTY, \\ UNIVERSITY EXTERNADO OF COLOMBIA)
}

\section{INTRODUCTION}

Legal protection of intangible assets related to intellectual property has suffered a substantial increase by the respective right holders, who are fiercely guarding them and willing to use every legal tool available in order to have their rights respected. This situation is completely expected and understandable if we take into consideration that in recent years it has been proven that these assets are the most valuable ones, in comparison to traditional tangible assets. As a result, litigation cases regarding disputes on intellectual property matters are in the center of attention in the legal world. In the present note, we intend to discuss parody ${ }^{1}$ as an exception - or defense - to allow the use of copyrighted works or protected trademarks by unauthorized parties. Precisely, we are going to approach parody, taking in consideration the case Louis Vuitton Malletier S.A. v. My Other Bag Inc., 156 F. Supp. 3d 425 (S.D.N.Y. 2016).

According to the Oxford Dictionary, parody has two main meanings, the first one defines it as: "An imitation of the style of a particular writer, artist, or genre with deliberate exaggeration for comic effect" while the second one states that parody is: "An imitation or version of something that falls far short of the real thing; a travesty" 2 . As it was correctly pointed out by Sakulin Wolfgang "while copyright

\footnotetext{
* Candidate to Law Degree at Universidad Externado de Colombia and research assistant on the Intellectual Property Department of the same University. Bogotá, D. C., Colombia. DoI: https://doi.org/10.18601/16571959.n24.10

1 Definition of parody: Parody is simultaneously humor, a form of commentary, a social critic and an ancient art, with the potential to shock or offend its readers. MEAD, Frank. Cocaine, coffee mugs, sex, and bug killing floor wax: Welcome to the realm of parody and the likelihood of confusion. Thomas Jefferson Law Review. San Diego: Thomas Jefferson School of Law, 1999, 21, p. 305. IssN: 1090-5278.

2 Definition of parody according to the Oxford Dictionary. Available at https:// en.oxforddictionaries.com/definition/parody
} 
and trademark protection seek to promote one or two primary interpretations of a work, parody seeks to do the opposite by creating a multifaceted view"3.

Trademarks and copyrighted works are the common targets of parody today ${ }^{4}$. And for sure Louis Vuitton, the Paris-based design house that happens to be one of the most valuable and prestigious design house, according to Forbes, can have a word in that. The company has been recognized to be over the top diligent regarding the protection of its most treasured assets, which are of course those related to intellectual property. The prior because "It is one of the most profitable brands in the world with profit margins north of 30\%" . One of the last encounters of Louis Vuitton with intellectual property litigation has мов as counterpart, a Los Angeles based company founded in 2011. This company designs, produces and sells canvas bags with designer lookalike bags of luxury and well-known brands as Louis Vuitton, Balenciaga, YsLV among others, as shown in the following image:

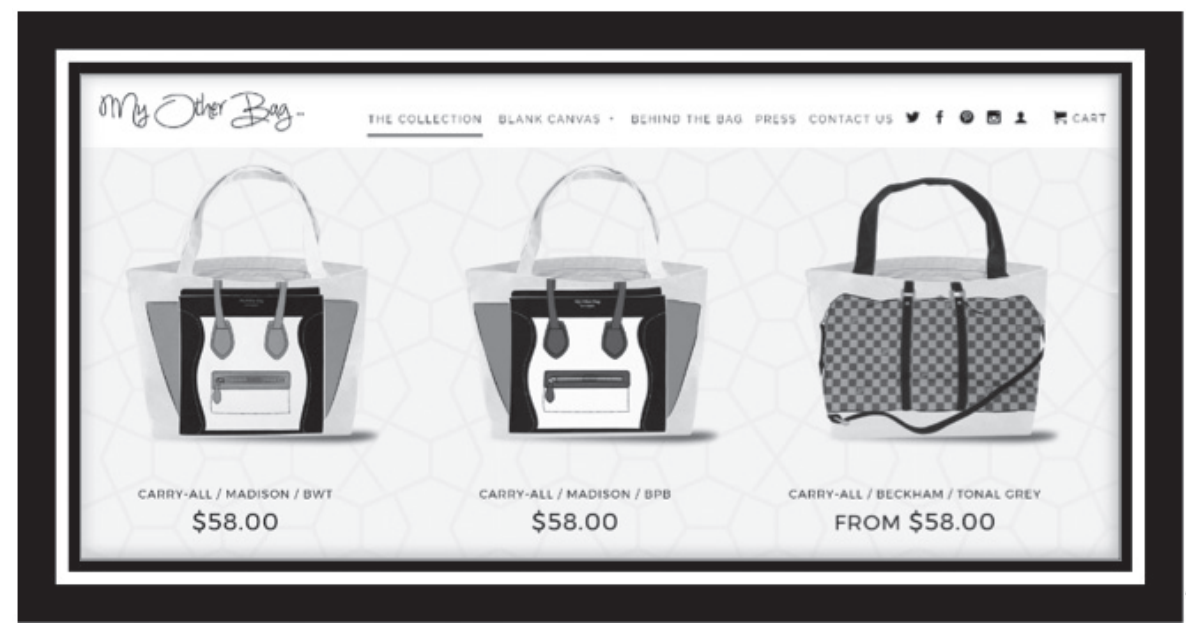

Screen shot taken from the official website of My Other Bag. (9/10/2017). Available at https://www.myotherbag. com/collections/my-other-bag

мов's canvas tote bags are distinguished because they have the text "My Other Bag..." on one side of the bag, while the other side contains an illustration of different iconic luxury designer's handbags and are sold for prices between USD38 and USD 58. The bags are advertised as "eco-friendly, sustainable tote bags playfully

3 Sakulin, Wolfgang. Trademark protection and freedom of expression: An Inquiry into the conflict between trademark rights and freedom of expression under European. Alphen aan den Rijin, The Netherlands: Wolters Kluwer Law \& Business, 2010, pp. 6-7.

4 Machado Pontes, Leonardo. Trademark and freedom of speech: A comparison between the US and the EU System in the awakening of Johan Deckmyn v. Helena Vandersteen. Geneva: OMpi, 2015, p. 2. Available at http://www.wipo.int/edocs $/ \mathrm{mdocs} / \mathrm{mdocs} / \mathrm{en} /$ wipo_ipl_ge_15/wipo_ipl_ge_15_t3.pdf

5 The world's most valuable brands. Forbes Magazine. Issn: 0015-6914. Available at https://www.forbes.com/companies/louis-vuitton/ 
parodying the designer bags we love, but practical enough for everyday life" ${ }^{6}$. On the contrary, Louis Vuitton's high-quality handbags and other luxury goods often sold for thousands of dollars.

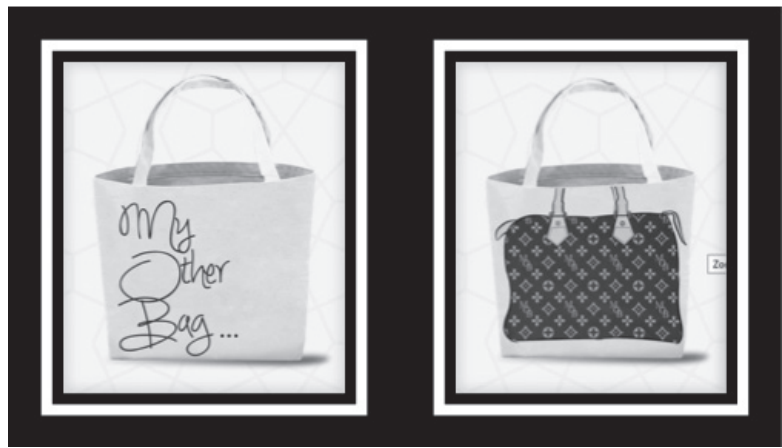

Screen shot taken from the official website of My Other Bag, showing both sides of their Zoey -Tonal Brown reference bag. (9/10/2017). Available at https://www.myotherbag.com/collections/my-other-bag/products/ zoey-tonal-browns

\section{THE SUIT FILED BY LOUIS VUITTON V. MY OTHER BAG}

On June 2014, Louis Vuitton filed a suit in the Southern District of New York City against мов. The claims were classified into three categories; trademark dilution claims, trademark infringement claims and copyright infringement claims. Louis Vuitton argued that at least seven (7) designs of мов infringed their trademarks and copyrights on the Toile Monogram design, that has been a brand signature since 1896, as well as the individual protected design of each of the flowers part of the toile monogram. Additionally, it infringed their insignia Damier design that goes back to 1888 , the different color treatments of it and the monogram multicolored designs from 2002. All of them illustrated below:

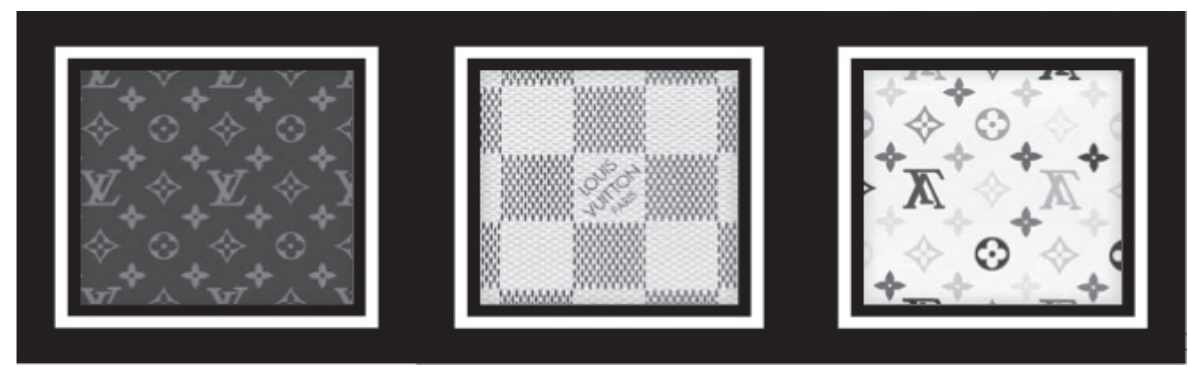

Images available at https://snobswap.com/blog/wp-content/uploads/2017/07/lvmonogram.jpg/ https://modeoflaw.files.wordpress.com/2015/05/louis-vuitton-damier-azur-check-grey-ivory-print.png/ http://www.bragmybag. com/wp-content/uploads/2014/07/louis-vuitton-monogram-multicolor-canvas.jpg

6 (Declaration Tara Martin Supp.Def.'s Mot.Summ J. (Docket No. 52). Included in Louis Vuitton Malletier S.A. v. My Other Bag, 156 F. Supp. 3d 425 (S.D.N.Y. 2016). 
As for the first claim, it is supported on $\$ 1125$ of the 15 U.S. Code and $\$ 360$-1 of the New York General Business Law. Louis Vuitton argued that the bags blur the distinctiveness of the Louis Vuitton's brand and the exclusiveness and uniqueness that represents them. In general, dilution occurs when the unauthorized use of a famous mark reduces the public's perception that the mark signifies something unique, singular, or particular"' Precisely in the case of dilution by blurring, the new use of famous trademarks may cause "consumers to form new and different associations with plaintiff's mark" thereby diluting the value of the mark ${ }^{8}$. In order to succeed on a dilution, claim under federal law, a plaintiff must prove':

1. That the trademark is truly distinctive or has acquired secondary meaning

2. A likehood of dilution... as a result of "blurring"

At this point it is important to bear in mind that some uses of trademarks are not actionable as dilution by blurring. For example "[a]ny fair use ... of a famous mark by another person other than as a designation of source for the person's own goods or services, including use in connection with ... identifying and parodying, criticizing, or commenting upon the famous mark owner or the goods or services of the famous mark owner" ${ }^{10}$. The court concluded referring to this claim that мОв's bags are protected by fair use, and the use of their marks constitutes parody ${ }^{11}$. The tote bags pose no danger of impairing the distinctiveness of the mark, and Louis Vuitton failed to prove the opposite, and takes a narrow view of what constitutes parody ${ }^{12}$.

As for the second claim related to trademark infringement, the design house stated that the company has been protecting and building their brand for over a century, which implies substantial investment and effort that is being risked, due to MOB's product being sold at the market. Louis Vuitton argues as well that its handbags are directly competitive with мов's totes and attract similar consumers $^{13}$. It also states that мов aims to create an erroneous association, consistent in making believe the customers that мов's designers are endorsed or authorized by Louis Vuitton to design and sale their bags, and that can be ratified taking as a fact that мов selected the same channels of distribution.

For this type of cases courts apply the eight- factor balancing test, known in the Second Circuit as the Polaroid Factors ${ }^{14}$, the objective of the test is to determine

7 H.R Rep. No. 109-23, at 4 (2005), as reprinted in 2006 U.S.C.C.A.N 1091, 1092.

8 Visa Intern. 610 F.3d at 1090. Louis Vuitton Malletier, S.A. v. My Other Bag, INC.14-CV-3419(JMF), p. 7.

9 Ergowerx Int'1, LLC v. Maxell Corp. of Am., 18 F. Supp.3d 430, 451(S.D.N.Y.2014)

(quoting Strange Music, Inc v. Strange Music, Inc., 326 F. Supp. 2d 481, 496

(S.D.N.Y.2004).

1015 U.S. Code $\$ 1125$ (c) (3).

11 Louis Vuitton Malletier S.A. v. My Other Bag Inc., 156 F. Supp. 3d 425 (S.D.N.Y. 2016).

12 Ibid.

13 (Louis Vuitton's Opp'n23) Louis Vuitton Malletier S.A. v. My Other Bag Inc., 156 F. Supp. 3d 425 (S.D.N.Y. 2016).

14 The test was first articulated by Judge Friendly in Polaroid Corp. v. Polarard Elecs. Corp., 287 F.2d 492 (2d Cir. 1961). The eight factors are (1) strength of the trademark; 
whether a likelihood of confusion exists between the two trademarks. In order to verify a trademark infringement, the mere comparison of the two products it's not sufficient, the context is also relevant because the setting in which the designation is used affects its appearance and colors the impression conveyed by $\mathrm{it}^{15}$. In the image shown below, one can see the comparison between the two products (one the right an original Louis Vuitton, on the left мов's canvas bag):
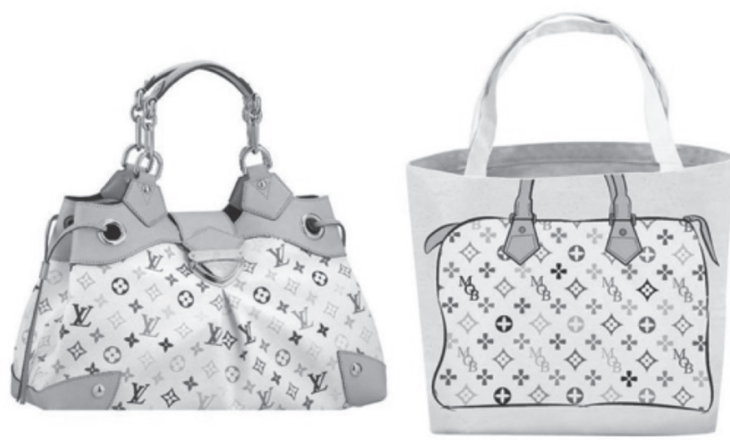

Louis Vuitton Looking to Take "My Other Bag" Case to Supreme Court. Mayo 22 de 2017.Picture Available at: http://www.thefashionlaw.com/home/louis-vuitton-looking-to-take-my-other-bag-case-to-supreme-court

At this point the Court declared taking into consideration a previous case, that Louis Vuitton's marks are so well known that consumers are likely "both immediately to recognize the target of the joke and to appreciate the obvious changes to the marks that constitute the joke"16. Furthermore, the differences between the two products are evident, and мов's depiction of the bag can be catalogued as cartoonish, not to mention the quality of the goods, thus confusion is unlikely to happen. When the entirety of the bag is considered, there is no credible risk that a reasonably prudent consumer would think Louis Vuitton "sponsored or otherwise approved" of MOB's totes ${ }^{17}$.

For the final claim regarding the copyright infringement, the Court comes to the conclusion that according to the prior circumstances evidenced above, any use by мов of copyrightable elements of Louis Vuitton's prints qualify as a matter of law as "fair use". Parody, like other forms of comment or criticism, "has an obvious claim to transformative value" and may therefore be "fair use" under the

(2) similarity of marks; (3) proximity of the products and their competitiveness with one another; (4) evidence that the senior user may bridge the gap by developing a product for sale in the market of the alleged infringer's product; (5) evidence of actual consumer confusion; (6) evidence that the imitative mark was adopted in bad faith; (7) respective quality of the products; and (8) sophistication of consumers in the relevant market.

15 Tommy Hilfiger, 221 F. Supp.2d at 417 (quoting Hormel Foods, 73 F.3d at 503).

16 Tommy Hilfiger, 221 F. Supp. 2 d at 416

17 Louis Vuitton Malletier S.A. v. My Other Bag Inc., 156 F. Supp. 3d 425 (S.D.N.Y. 2016). 
Copyright Act $^{18}$. And even when in the present case, the fact that MOB's business profits come from the sale of the tote bags, the Court was clear by stating that Parody, even when done for commercial gain, can be fair use ${ }^{19}$.

Louis Vuitton requested a preliminary injunction that consisted in three components. The first one, to order мов to pull all the infringing goods from the web site and the market, second of all the destruction of them and everything associated with them, and finally obtain monetary damages. The preliminary injunction was denied.

On January of 2016, the southern District of Ney York denied Louis Vuitton's motion for summary judgement. Judge Jesse Furman stated that the canvas tote bags are parodies, and as such, they are not actionable sources of trademark infringement or dilution. In addition, Furman insisted that Louis Vuitton should accept the implied compliment in a parody as such, and that this would eventually reinforce and enhance the distinctiveness and notoriety of Louis Vuitton and not the opposite as they alleged. The conclusion of the Court read as follows: "мов's use of Louis Vuitton's marks in service of what is an obvious attempt at humor is not likely to cause confusion or the blurring of the distinctiveness of Louis Vuitton's marks; if anything, it is likely only to reinforce and enhance the distinctiveness and notoriety of the famous brand" 20 .

\section{THE APPEAL BY LOUIS VUITTON}

After the decision by the Southern District of New York, Louis Vuitton appealed to the Second Circuit Court of Appeals. Judges Gerard Lynch, Guido Calabresi and Reena Raga composed the panel. Louis Vuitton claimed that the tote bags did not amount to parodies, because using the brand's famed marks to profit from them, affected their market and so, there were actionable sources of trademark infringement and dilution. Nonetheless, Judge Lynch accused Louis Vuitton of acting like a trademark bully against smaller companies and having an overaggressive attitude and prosecution of Intellectual property cases, which could lead eventually into unreasonable litigation.

Judge Lynch pointed out that a parody consisted on two contradictions with simultaneous messages. The first one that it is the original and the second one stating that it is not the original and it is instead a parody. According to this, мов met these requisites, even if their bags constitute a subtle joke. On the other hand, according to their definition of parody, referring to a work that imitates or mimics another work for comic effect or commentary, in the present case, it is evident that MOB's bags do exactly that; rather than simply exploiting the popularity of the underlying trademarks or other intellectual property rights as the means not 
only to create confusion among consumers but also to attract a bigger amount of costumers.

In accordance to the prior, the Court of Appeals ${ }^{21}$ shared the arguments and conclusions exposed by Judge Furman and affirmed the decision of the Southern District Court of New York. The only pending decision is regarding the amount of attorney's fees awarded tо мов. In April 2017 мов was seeking nearly 1 million dollars in legal fees and filed a memorandum of law in support of мов's Application for Award of Attorney's fees.

\section{LOUIS VUITTON SEEKS HEARING EN BANC}

In mid-January 2017, Louis Vuitton sought a hearing en Banc ${ }^{22}$. This time Louis Vuitton argued that the Second Circuit panel had ruled in conflict with existing case law and against the case set forth by the Supreme Court. The existing case law states that a parody must be directed at the senior user or the senior users trademark itself, and it cannot be merely vague social criticism or comment. In this sense, Louis Vuitton said the parody must have been directed specifically to its brand and not include other luxury brands. The Second Circuit decided to deny the petition to rehear Louis Vuitton's suit, and to let stand on the ruling.

\section{SUPREME COURT}

On May of 2017, Louis Vuitton filed a petition for a writ of certiorari from the Supreme Court. The purpose of this action is to have the decision of a lower court reviewed, but it is unlikely to happen, the success rate of a petition of this nature is extremely low ${ }^{23}$. The brand's ground to file the petition can be summarized in the following: "Permitting an entire business model premised on the exploitation of famous marks to sell knock-off products is flatly at odds with the Congress's intent to protect famous marks from dilution", and what Louis Vuitton sought with the petition is evidenced in the following statement: "The Supreme Court's intervention is necessary to establish a nationally uniform test for identifying parody in dilution cases, to restore the careful balance between trademark protection and First amendment rights that Congress struck in the TDRA (Trademark Dilution Revision Act) and to prevent the widespread, irreversible devaluation of famous marks".

21 Louis Vuitton Malletier S.A. v. My Other Bag, Inc., No. 16-241-cv (2d Cir. Dec. 22, 2016).

22 The full bench, full court. A "sitting in banc" is a meeting of all the judges of a court, usually for the purpose of hearing arguments on demurrers, points reserved, motions for new trial, etc., as distinguished from the sitting of a single judge at the assises or at nisi prius and from trials at bar. Black's Law Dictionary, 2nd ed.

23 Success Rate of a Petition for Writ of Certiorari to the Supreme Court. Supreme Court Press. Available at: http://www.supremecourtpress.com/chance_of_success.html 
But despite Louis Vuitton's plea, in October 2 of $2017^{24}$ the Supreme Court refused to revive the suit and left the ruling by the United States Court of Appeals for the Second Circuit intact, upholding the U.S District Court for the Southern District of New York's January 2016 ruling.

\section{CONCLUSIONS}

Louis Vuitton has been proven to be a trademark bully in the industry, bringing to court groundlessness cases like the one analyzed in the present note, and others such as Louis Vuitton v Haute Diggity $\operatorname{Dog}^{25}$, Louis Vuitton v Nadia Plesner ${ }^{26}$ or Louis Vuitton v. Warner Brothers ${ }^{27}$. The strategy they use is to multiply the cost of litigation making the counterpart spend time and money defending themselves from groundless motions. For this reason, high court decisions like this one help prevent and mainly discourage this type of behavior, through the elevated sums that they are forced to pay as attorney fees if bad faith of the plaintiffs is demonstrated. Reducing the situations that harm competitors and the industry, specifically the personal and financial hardship the smaller competitors have to go through if the case is not settled and goes to court.

Another notable outcome of the case, is concerning other defendants that are nowadays using a parody defense and targeting well known trademarks. This decision represents a big win for them since it reaffirmed the position that has been established in prior decisions in the matter, such as Louis Vuitton Malletier v. Haute Diggity Dog. Furthermore, it reveals that trademark trolls or trademark bullies are a growing phenomenon in the industry ${ }^{28}$.

\section{BIBLIOGRAPHY}

Ergowerx Int'l, LLC v. Maxell Corp. of Am., 18 F. Supp.3d 430, 451(S.D.N.Y.2014). Louis Vuitton Malletier S.A. v. My Other Bag Inc., 156 F. Supp. 3d 425 (S.D.N.Y. 2016).

Louis Vuitton Malletier, S.A. v My Other Bag, Inc.14-CV-3419(JMF).

Louis Vuitton Malletier S.A. v. My Other Bag, Inc., No. 16-241-cv (2d Cir. Dec. 22, 2016).

24 Louis Vuitton Malletier S.A. v. My Other Bag, Inc., No. 17-72 (U.S. Oct. 2, 2017).

25 Louis Vuitton Malletier S.A. v. Haute Diggity Dog, LLC, 507 F.3d 252, 2007 U.S. App. LEXIS 26334, 84 U.S.P.Q.2D (BNA) 1969, Copy. L. Rep. (CCH) P29,476 (4th Cir. Va. Nov. 13, 2007)

26 Louis Vuitton Malletier S.A. v Nadia Plesner KG RK 10-214 Decision of 27 January 2011.

27 Louis Vuitton Malletier, S.A. v. Warner Bros. Entertainment Inc., No. 1:2011cv09436 28 Mandelson, Peter. Trademark trolls: Here to stay? INTA Bulletin. New York: International Trademark Association, 2015, 70(21). Available at https://www.inta.org/ INTABulletin/Pages/Trademark_Trolls_7021.aspx 
Louis Vuitton Looking to Take "My Other Bag" Case to Supreme Court. May 22, 2017.

Machado Pontes, Leonardo. Trademark and freedom of speech: A comparison between the US and the EU System in the awakening of Johan Deckmyn v. Helena Vandersteen. Geneva: OMPI, 2015, p. 2. Available at http://www.wipo.int/edocs/ mdocs/mdocs/en/wipo_ipl_ge_15/wipo_ipl_ge_15_t3.pdf

Mandelson, Peter. Trademark trolls: Here to stay? INTA Bulletin. New York: International Trademark Association, 2015, 70(21). Available at https://www. inta.org/INTABulletin/Pages/Trademark_Trolls_7021.aspx

Mead, Frank. Cocaine, coffee mugs, sex, and bug killing floor wax: Welcome to the realm of parody and the likelihood of confusion. Thomas Jefferson Law Review. San Diego: Thomas Jefferson School of Law, 1999, 21, p. 305. ISsN: 1090-5278.

Polaroid Corp. v. Polarard Elecs. Corp., 287 F.2d 492 (2d Cir. 1961).

SAKULIn, WolfGang. Trademark protection and freedom of expression: An Inquiry into the conflict between trademark rights and freedom of expression under European. Alphen aan den Rijin, The Netherlands: Wolters Kluwer Law \& Business, 2010, pp. 6-7.

Screen shot taken from the official website of My Other Bag. (9/10/2017). Available at https://www.myotherbag.com/collections/my-other-bag

Success Rate of a Petition for Writ of Certiorari to the Supreme Court. Supreme Court Press.

The world's most valuable brands. Forbes Magazine. Issn: 0015-6914. Available at https://www.forbes.com/companies/louis-vuitton/

Tommy Hilfiger, 221 F. Supp.2d at 417 (quoting Hormel Foods, 73 F.3d at 503). 